\title{
Potential Uses of Stormwater Runoff Sedimentgs Retained in a Constructed- Wetland/Storage-Tank
}

Usos potenciales de los sedimentos de escorrentía de agua lluvia retenidos en un humedal-construido/tanque-regulador

Submitted on: July 5, 2019| Accepted on: June 10, 2020 | Published: June 17, 2021

\author{
Maria Alejandra Pimiento ${ }^{a}$ \\ Pontificia Universidad Javeriana, Colombia \\ ORCID: 0000-0002-7691-7291 \\ Jaime Andrés Lara-Borrero \\ Pontificia Universidad Javeriana, Colombia \\ ORCID: 0000-0003-3247-7519

\section{Andrés Torres} \\ Pontificia Universidad Javeriana, Colombia \\ ORCID: 0000-0001-8693-8611
}

${ }^{a}$ Corresponding author. E-mail: mpimiento@javeriana.edu.co

DOI: https://doi.org/10.11144/Javeriana.iued25.pusr

How to cite this article:

M. A. Pimiento, J. A. Lara-Borrero, and A. Torres "Potential uses of stormwater runoff sediments retained in a constructed-wetland/storage-tank," Ing. Univ., vol. 25, 2021 [Online]. https://doi.org/10.11144/Javeriana.iued25.pusr 


\section{Abstract}

Objective: The goal of this work was to establish the quality conditions of the sediments retained in a constructedwetland/storage-tank, which are to be used as productive material. Materials and methods: Sediments were collected every fortnight for five months in 2016, with sediment traps specially designed for the study case, to analyze particle size distribution, total organic carbon, and heavy metals concentrations. Sediment and hydrological data processing were performed using principal component analysis and multiple correspondence analysis. Results: The maximum measured concentrations were $110.80 \mathrm{mg} / \mathrm{kg}, 263.25 \mathrm{mg} / \mathrm{kg}, 798.85 \mathrm{mg} / \mathrm{kg}$, and $3067 \mathrm{mg} / \mathrm{kg}$ for $\mathrm{Cr}, \mathrm{Cu}, \mathrm{Pb}$, and $\mathrm{Zn}$ respectively; for total organic carbon was $20.6 \mathrm{mg}$. The sediment particles were considered thin $(\mathrm{D} 50<150 \mu \mathrm{m})$. Interesting relationships between rainfall and sediment characteristics were found. In shorter dry seasons, higher particle diameter, lower concentrations of heavy metals, and higher concentrations of total organic carbon were seen. Conclusions: Sediments are suitable for use in activities such as land remediation, vegetation of soils that are not for agricultural use, and as materials for ornamental and recreational areas. It is possible to use the sediments in embankments as tolerable soil for fillings of concrete structures and culverts in the core or foundation area.

Keywords: Productive material, rainfall characteristics, sediments characteristics, stormwater harvesting systems.

\section{Resumen}

Objetivo: el objetivo de este trabajo fue establecer las condiciones de calidad de los sedimentos retenidos en un humedalconstruido/tanque-regulador para ser utilizado como material productivo. Materiales $y$ métodos: los sedimentos se recolectaron cada quince días durante cinco meses en 2016, con trampas de sedimentos especialmente diseñadas para el caso de estudio, para analizar la distribución del tamaño de partículas, el carbono orgánico total y las concentraciones de metales pesados. El procesamiento de datos de sedimentos e hidrológicos se realizó mediante análisis de componentes principales y análisis de correspondencia múltiple. Resultados: las concentraciones máximas medidas fueron $110,80 \mathrm{mg} / \mathrm{kg}, 263,25 \mathrm{mg} / \mathrm{kg}, 798,85 \mathrm{mg} / \mathrm{kg}$ y $3067 \mathrm{mg} / \mathrm{kg}$ para $\mathrm{Cr}, \mathrm{Cu}, \mathrm{Pb}$ y $\mathrm{Zn}$, respectivamente; para el carbono orgánico total fue de 20,6 mg. Los granos de los sedimentos se consideraron finos (D50 $<150 \mu \mathrm{m})$. Se encontraron relaciones interesantes entre la lluvia y las características del sedimento: en temporadas secas más cortas, mayor diámetro de partícula, menores concentraciones de metales pesados y mayores concentraciones de carbono orgánico total. Conclusiones: los sedimentos son adecuados para su uso en actividades tales como la remediación vegetación de suelos que no son para uso agrícola y como materiales para áreas ornamentales y recreativas. Es posible utilizar los sedimentos en los terraplenes como suelo tolerable para rellenos de estructuras de hormigón y alcantarillas en el área central o de cimentación.

Palabras clave: material productivo, características hidrológicas, características de sedimentos, sistema de aprovechamiento de agua lluvia. 


\section{Introduction}

Sediments are part of the aquatic ecosystem, and their management is an environmental concern by the quantities dredged in different waterbodies as well as their disposal, relocation, or reuse [1]. Generally considered as waste, incorrect disposal may also cause environmental problems [2]. For this reason, nowadays there is an increasing interest in knowing the risk associated with their management [3], [4]. Commonly, the sediments extracted from different water systems are rejected into sanitary landfills, confined for aquatic disposal, or discharged into the sea [5].

Rainwater systems have structures that allow the entry of stormwater runoff into the drainage or treatment system. These structures have a significant effect on water, capturing the sediments and other pollutants that are washed from surfaces during rainfall, preventing them from being deposited in downstream sewerage in the receiving waters and as part of the stormwater treatment train concept [6].

According to the sediment quality, they could be used in different activities such as soil remediation, agriculture, or raw construction material [4], [5], [7]-[9]. The chemical characterization of the sediments provides information about risks associated with their management [3]. The potential to be used depends mainly on the heavy metals, polycyclic aromatic hydrocarbons, and nutrient concentrations. The stormwater sediment concentration of pollutants might vary with respect to the size of the sediment particle [10], the type of land use, the contact surface of stormwater (roads, parking lots, roofs of different materials) [11], the rain intensity, the storm duration, and the dry periods [11], [12]. Likewise, sediments from paved surfaces have been documented to contain elevated levels of multiple pollutants. However, their concentrations are associated with the geographical location, the type of road and traffic, and the runoff; but the characterization data are limited [3]. Some countries have determined threshold concentrations for the sediments that could have an ecological impact or a risk for human health as shown in table 1. Colombia does not have any regulation for sediment management and their pollutant threshold concentrations; however, Cedeño Ochoa [14] defined Cadmium (Cd), Chromium $(\mathrm{Cr})$, Cooper $(\mathrm{Cu})$, Nickel $(\mathrm{Ni})$, Lead $(\mathrm{Pb})$, and $\mathrm{Zinc}(\mathrm{Zn})$ as the metals that create a health risk. 
Table 1. Threshold heavy metal concentrations in sediments Expressed in $\mathrm{mg} / \mathrm{Kg}$

\begin{tabular}{cccccccccc}
\hline COUNTRY & & As & $\mathbf{C d}$ & $\mathbf{C r}$ & $\mathbf{C u}$ & $\mathbf{P b}$ & $\mathbf{H g}$ & $\mathbf{N i}$ & $\mathbf{Z n}$ \\
\hline \multirow{2}{*}{ Canada [15] } & ISQG & 6 & 1 & 37.3 & 35.7 & 35 & 0.17 & - & 123 \\
\cline { 2 - 10 } & PEL & 17 & 4 & 90 & 197 & 91.3 & 0.486 & - & 315 \\
\hline \multirow{3}{*}{ Wisconsin/USA [16] } & TEC & 10 & 1 & 43 & 32 & 36 & 0.18 & 23 & 120 \\
\cline { 2 - 9 } & MEC & 21 & 3 & 76.5 & 91 & 83 & 0.64 & 36 & 290 \\
\cline { 2 - 10 } & PEC & 33 & 5 & 110 & 150 & 130 & 1.1 & 49 & 460 \\
\hline Netherland [17] & & 29 & 1 & 100 & 36 & 85 & 0.3 & 35 & 140 \\
\hline \multirow{2}{*}{ Norway [18] } & Level 1 & 18 & 84 & 660 & 84 & 150 & 0.52 & 42 & 139 \\
\hline Australia/New & Level 2 & 1 & 1 & 5 & 163 & 3.6 & 0.71 & 50 & 500 \\
\hline Zealand [19] & Low risk & 9 & 2 & 80 & 65 & 50 & 0.15 & 21 & 200 \\
\hline Hong Kong/China & Toxicity effects & 70 & 10 & 370 & 270 & 220 & 1 & 52 & 410 \\
\cline { 2 - 9 } [20] & LCEL & 12 & 2 & 80 & 65 & 75 & 0.5 & 40 & 200 \\
\cline { 2 - 9 } & UCEL & 42 & 4 & 160 & 110 & 110 & 1 & 40 & 270 \\
\hline
\end{tabular}

ISQG: Interim Sediment Quality Guideline. PEL: Probable Effect Level. TEC: Threshold Effect Concentration. MEC: Midpoint effect concentration. PEC: Probable Effect Concentration. Level 1: Ecological Impact. Level 2: Risk to Human Health. LCEL: Lower Chemical Exceedance Level. UCEL: Upper Chemical Exceedance Level.

\section{Source: Own source.}

The recycling of sediments and other materials is highly valued, as the costs of removing and disposing of the sediments continuously increase [7]. Therefore, there is a need to know the behavior of sediments in stormwater systems since their management involves costs. In adherence with Colombian legislation, any material that has no direct or indirect use value is likely to be incorporated into a production process. The use of solid waste in the activities of reuse and recycling must provide health, environmental, social and economic benefits [21]. For this reason, it is necessary to find alternatives for sediment management, such as productive use.

Some authors analyzed the economic feasibility and possible uses of sediments dredged in reservoirs and lakes as an option for agricultural purposes and soil restoration because they contain nutritional elements needed in soils as well as low concentrations of heavy metals. However, it is necessary to analyze that the receiving soil has similar or lower characteristics than the sediments. Besides, they can have high clay contents and can be useful for water storage or as a fertilizer due to high nutrient concentrations. Sandy sediments could be used as soil on their own or as a construction material [4], [9], [22]. Also, Cheng et al. [7] used the sediment dredged for a reservoir and the construction waste to create a non-sintered cured brick classified as a green building material that provides economic benefits. Currently, there is a need to identify specific uses for sediments extracted from waterbodies with similar conditions. 
The objective of this work was to establish the quality conditions of the sediments retained in a constructed-wetland/storage-tank (CWST) to be used as a productive material.

\section{Materials and Methods}

The sediments were collected from two sand traps of the CWST located at the Pontificia Universidad Javeriana Bogotá (PUJ) (figure 1), which receives the runoff water from the parking lot building, basin number $12(0.81 \mathrm{Ha})$, in the east sand trap and the runoff water from the soccer field and surroundings, basin number $2(2.73 \mathrm{Ha})$, in the west sand trap [23].

\section{Figure 1. Sample site}
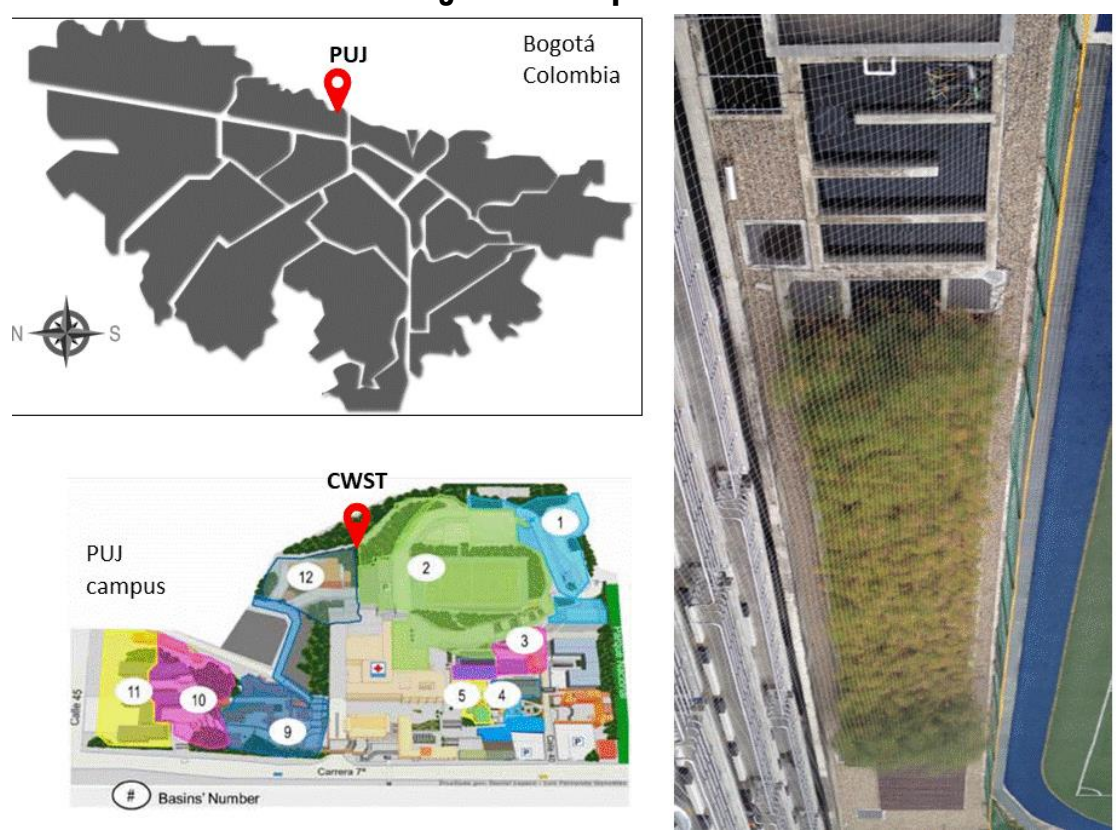

Source: Own source.

Samples were taken every fortnight for five months (April 13, 2016, to September 29, 2016), with sediment traps especially designed for the study case, which did not alter the water flow and collect the sedimented particles during each period (figure $2 \mathrm{a}$ ). In each sand trap, we installed four sediment traps with 1.5 oz capacity. For each sand trap, we collected the samples in beakers (figure 2b) and carried them to the PUJ water quality laboratory to undertake physical (Particle Size Distribution [PSD]) and chemical analyses (Total Organic Carbon [TOC] and Heavy Metal [HM] concentrations). 
Figure 2. (a) Sediment trap. Capacity $1.5 \mathrm{oz}$, (b) Beaker with the collected samples

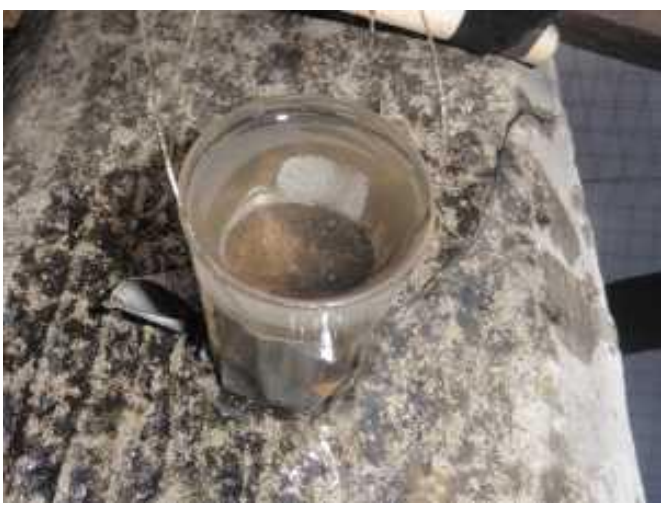

(a)

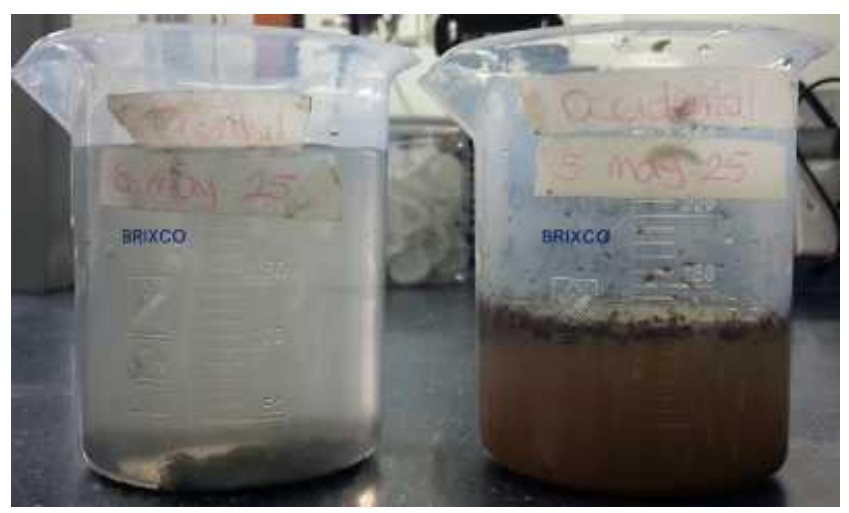

(b)

Source: Own source.

\section{Physical Characteristics}

A laser diffraction analysis was carried out in a range of $0.1 \mu \mathrm{m}$ to $1000 \mu \mathrm{m}$ with the Mastersizer 3000E to determine the PSD of sediments. This equipment reports the equivalent percentage of sample volume analyzed for each diameter. The analysis was done twice obtaining six measurements per sample; these values were accumulated to obtain the representative diameters (e.g., D10, D50, D90) and subsequently calculate the uniformity coefficient (Uc) which was proposed by Allen Hazen as the relationship between D60 and D10. The PSD with Uc $<3$ are considered very uniform, with Uc $<5$ are considered uniform, and Uc $\geq 5$ are considered well graded, that is to say with an abundance of sizes [24].

\section{Chemical Characteristics}

The samples were filtered, dried, weighed, and digested with HNO3 as established by EPA 3051A [25] to determine HM concentrations in sediments. A semi-qualitative analysis by inductively coupled plasma emission spectroscopy (ICPE-9800) shown the elements present in the samples allowed us to select $\mathrm{Cr}, \mathrm{Cr}, \mathrm{Pb}$, and $\mathrm{Zn}$ (figure 3) as the $\mathrm{HM}$ with relevant concentrations in sediments. We undertook three repetitions of ICP quantitative analysis to determine the HM concentrations in each sample. Also, the TOC was used as an indicator of the presence of the chemical components of organic matter; it was measured with the TOC-L and SSM-5000A equipment. 
Figure 3. Boxplot semi-qualitative analysis

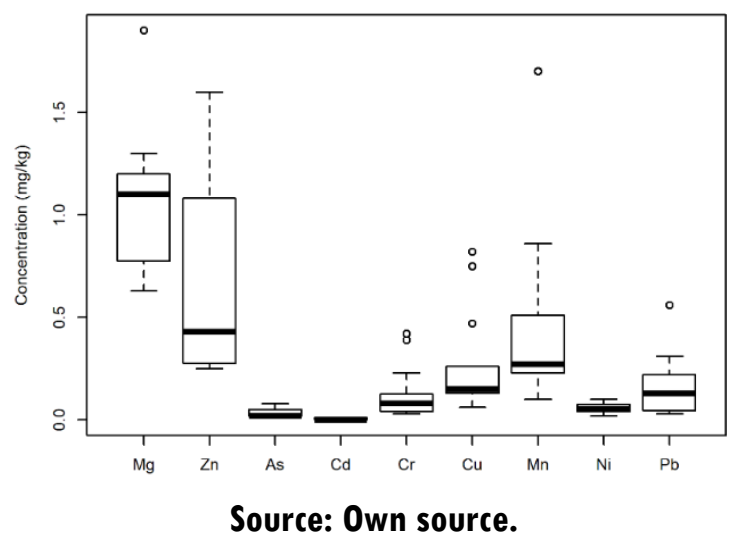

\section{Hydrological Characteristics}

In a previous work the hydrological characterization was analyzed [12]. We collected the daily rainfall data from the El Granizo (PA - 036) rainfall station and a rainfall station located inside the PUJ campus. The variables analyzed were the following ones: total precipitation (Htot), average intensity (Iprom), maximum intensity (Imax), number of days with antecedent dry weather (Tseco), number of days with rainfall (Tlluvia), and net average intensity (Ipromneta). The analysis of the hydrological data was carried out categorically classifying them as low, medium, and high.

\section{Statistical Analysis}

The processing of data obtained from laboratory analyses was done numerically and categorically, assigning to each value a category: Low, Medium, or High. The analysis was made in R with the ade4 library by Principal Component Analysis (PCA) and by Multiple Correspondence Analysis (MCA) to determine the most important variables influencing the variability between samples and to find the relationships between the variables. The computational analysis is detailed in a previous paper [12]. A Wilcoxon Test was used to determine significant differences between measurements.

\section{Uses}

According to the chemical characteristic to reuse some waste, the pollutants in materials have to be lower than the threshold established in some guidelines, especially for wastewater sludge, as shown in table 2. These parameters could be applied to stormwater runoff sediments. These guidelines usually define the permissible values for reuse materials in agriculture; also, some guidelines defined values for other activities. Colombia defined the permissible values for two categories of reuse: Category A/Agriculture as organic 
fertilizer; Category A/Other as land remediation of contaminated soils; Category B forestry, for the stabilization of slopes on roads, rehabilitation of lands for recreation, gardens, parks, and green areas [21]. Tasmania also defined three classes for allowable land application use: Class 1 for home lawns and gardens, public contact sites, and urban landscaping; Class 2 for agriculture, forestry, and land rehabilitation; and Class 3 for disposal at a waste depot or landfill [26].

Table 2. Threshold Heavy Metal Concentrations for Material Reuse expressed in $\mathbf{m g} / \mathbf{k g}$

\begin{tabular}{cccccccccc}
\hline COUNTRY & & As & $\mathbf{C d}$ & $\mathbf{C r}$ & $\mathbf{C u}$ & $\mathbf{P b}$ & $\mathbf{H g}$ & $\mathbf{N i}$ & $\mathbf{Z n}$ \\
\hline \multirow{3}{*}{ Colombia [21] } & Cat A/Agriculture & 15 & 0.7 & 70 & 70 & 45 & 0.4 & 25 & 200 \\
\cline { 2 - 9 } & Cat A/Other Uses & 140 & 39 & 1200 & 1500 & 300 & 17 & 420 & 2800 \\
\cline { 2 - 9 } & Cat B & 75 & 85 & 3000 & 4300 & 840 & 57 & 420 & 7500 \\
\hline Denmark [27] & Agriculture & - & 0.5 & 30 & 40 & 40 & 0.5 & 15 & 100 \\
\hline FAO [28] & Agriculture & 50 & 3 & 400 & 80 & 300 & 1 & 50 & 200 \\
\hline \multirow{2}{*}{ Tasmania [26] } & Class 1 & 20 & 3 & 100 & 100 & 150 & 1 & 60 & 200 \\
\cline { 2 - 9 } & Class 2 & 20 & 20 & 500 & 1000 & 420 & 15 & 270 & 2500 \\
\hline USA [29] & Land Applications & 41 & 39 & - & 1500 & 300 & 17 & 420 & 2800 \\
\hline South Africa [30] & Agriculture & 40 & 40 & 1200 & 1500 & 300 & 15 & 420 & 2800 \\
\hline
\end{tabular}

\section{Source: Own source.}

According to the sediment PSD, it can be used as a construction material like aggregate; also the particles should be clean, resistant, free of organic matter, and they should not contain harmful substances that could harm the construction materials [31]. They can be used as well in fillings of concrete structures and culverts in the core or foundation area [32]. In Bogotá, Colombia, studies have been carried out for the reuse of sediments collected in rainwater system wells, finding that they can be used as pozzolans and Portland cement, in some cases calcium carbonate must be added to satisfy the demand [33].

Table 3. Requirements of materials for embankments

\begin{tabular}{lccc}
\hline \multicolumn{1}{c}{ Characteristics } & Selected soils & Suitable soils & Tolerable soil \\
\hline Maximum size $(\mathrm{mm})$ & $75 \mathrm{~mm}$ & $100 \mathrm{~mm}$ & $150 \mathrm{~mm}$ \\
\hline Percentage passing sieve no. 10 & $\leq 80 \%$ weight & $\leq 80 \%$ weight & - \\
\hline Percentage passing sieve no. 200 & $\leq 25 \%$ weight & $\leq 35$ weight & $\leq 35$ weight \\
\hline Maximum organic matter content & $0 \%$ & $\leq 1 \%$ & $\leq 2 \%$ \\
\hline
\end{tabular}

Source: Instituto Nacional de Vías [32].

\section{Results}

Although the samples collected come from basins with different characteristics, when performing the Wilcoxon test the results obtained showed that there are no significant differences between the characteristics analyzed in the sediments from the east and west 
sand traps, except for $\mathrm{Cu}$ and $\mathrm{Pb}$. (p values > 0,05). Thus, we analyzed variables obtained from laboratory tests without a spatial separation.

We compared the variance of HM concentrations in sediments obtained from the qualitative analysis by ICP with thresholds of HM concentrations for sediments shown in table 1. For $\mathrm{Cr}$, the measured concentrations vary between $3.93 \mathrm{mg} / \mathrm{kg}$ and $110.80 \mathrm{mg} / \mathrm{kg}$, with a median value of $35.84 \mathrm{mg} / \mathrm{kg}$. This value is lower than the safety limit concentration; however, according to [18] this concentration represents a human health risk (figure 4a). The $\mathrm{Cu}$ lowest and highest concentrations measured were $24.94 \mathrm{mg} / \mathrm{kg}$ and $263.25 \mathrm{mg} / \mathrm{kg}$ respectively, with a median value of $115.5 \mathrm{mg} / \mathrm{kg}$, which is higher than the low-risk level but lower than the probable effect level (figure $4 \mathrm{~b}$ ). The $\mathrm{Pb}$ concentrations, in general, exceed the established limits with a minimum of $106.83 \mathrm{mg} / \mathrm{kg}$, a maximum of 798.85 $\mathrm{mg} / \mathrm{kg}$ and a median of $331.45 \mathrm{mg} / \mathrm{kg}$ (figure $4 \mathrm{c}$ ). $\mathrm{Zn}$ concentrations are higher than the probable effect concentrations, in a range of $623.3 \mathrm{mg} / \mathrm{kg}$ to $3067 \mathrm{mg} / \mathrm{kg}$ (figure $4 \mathrm{~d}$ ).

\section{Figure 4. HM concentrations compared with threshold concentrations values in sediments}

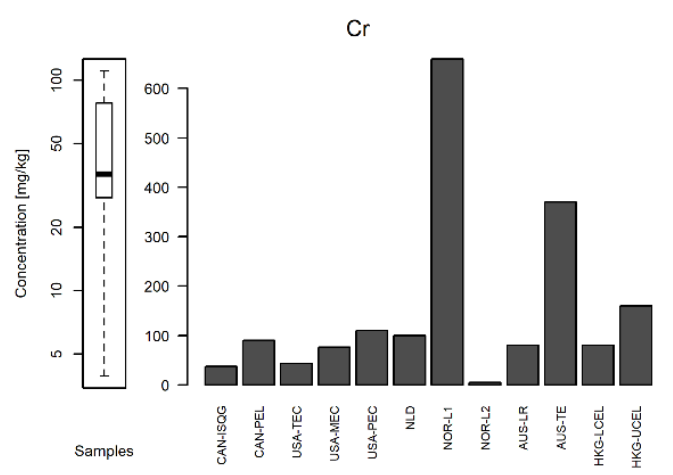

(a)

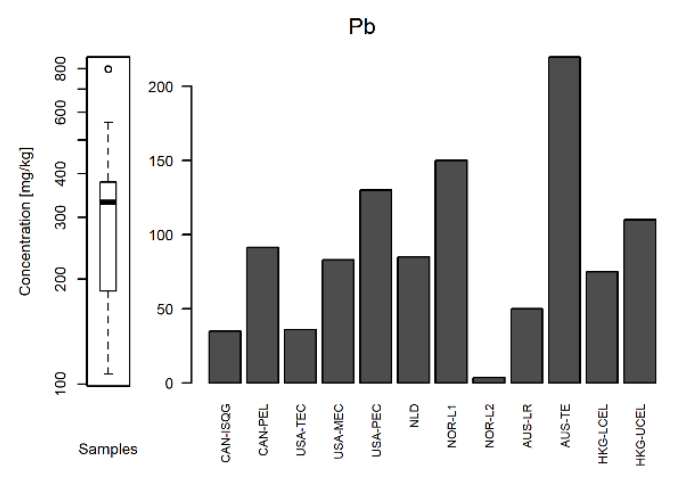

(c)

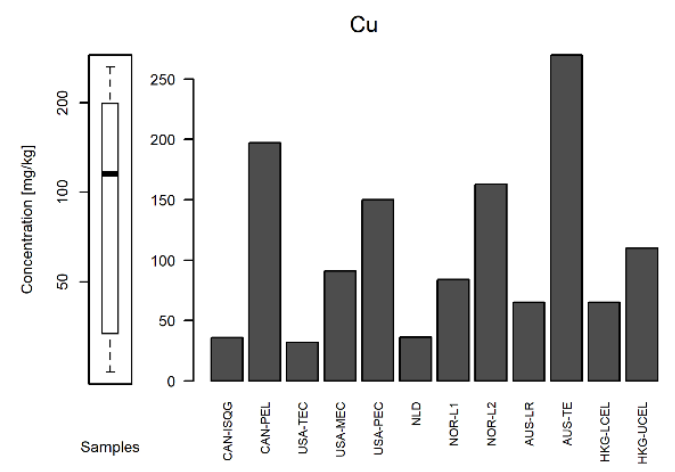

(b)

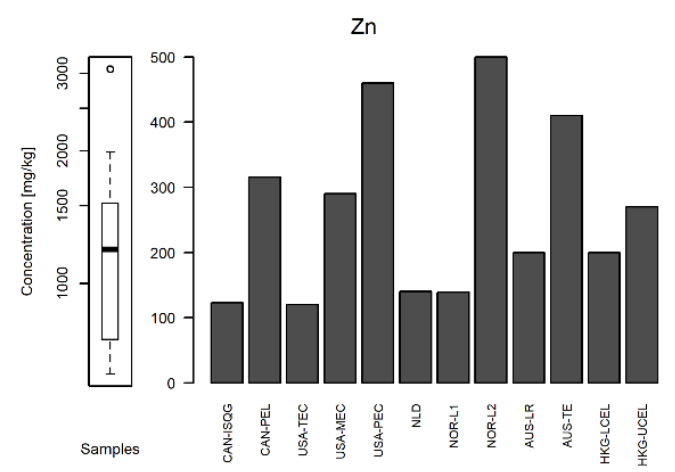

(d)

Source: Own source. 
We compared the HM concentrations of the CWST sediments with the limits for each use summarized in table 2. The threshold $\mathrm{Cr}, \mathrm{Cu}, \mathrm{Pb}$, and $\mathrm{Zn}$ concentrations for reuse, established in RAS Category A/Other, USA-land application and South Africa-agriculture are the same. As shown in figure 5, it is not possible to reuse the sediments for agriculture purposes due to the high HM concentrations; however, according to Tasmanian Class 2 and South African legislations, the sediments could be used for agriculture purposes. In general, it is possible to reuse them in land remediation, based on RAS Category A/Other, USAland application and Tasmanian Class 2; considering that few samples exceed the $\mathrm{Pb}$ allowed concentrations. For the Colombian regulation, it is possible to use the sediments in gardens and urban landscaping, nonetheless, the Tasmanian legislation is stricter for reuse in these activities.

\section{Figure 5. Reuse}

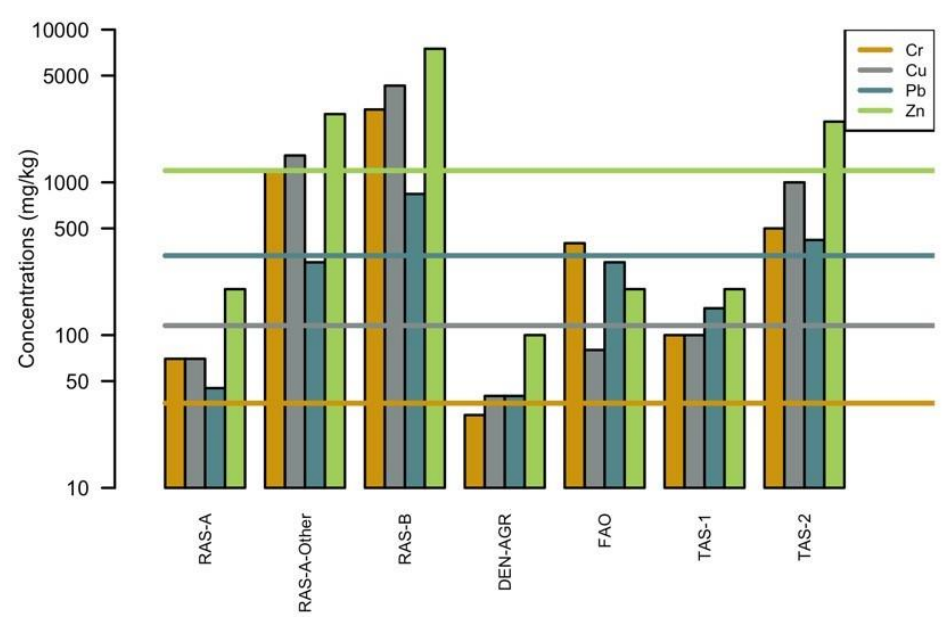

Source: Own source.

The sediment physical characterization and the organic matter content provide the information to evaluate their use as construction materials (table 3) based on the Colombian legislation. The PSDs obtained (figure 6) show that sampled sediments are very thin particles ( $\mathrm{D}_{50}$ between $48 \mu \mathrm{m}$ and $241 \mu \mathrm{m}$ ), which limits their uses. The TOC vary between $5.03 \mathrm{mg}$ and $20.6 \mathrm{mg}$, with a median value of $12.1 \mathrm{mg}$. According to the PSD, the sediments could be used in embankments as tolerable soil for filling concrete structures and culverts in the core or foundation area. However, the high content of organic matter does not favor its use. 
Figure 6. Particle Size Distribution (PSD)

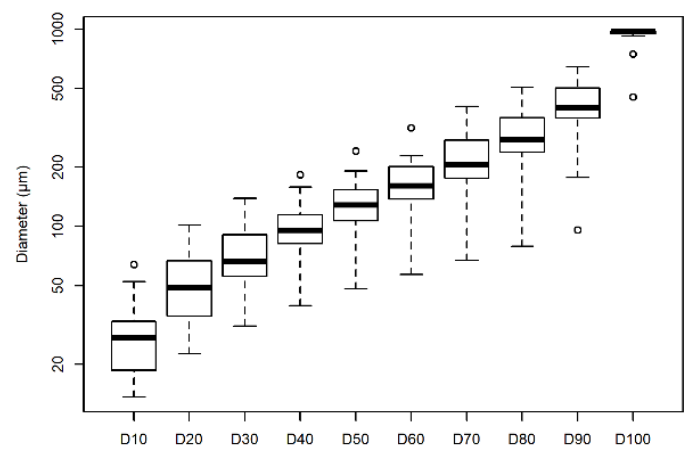

Source: Own source.

From the results obtained with the PCA analysis (figure 7) it is possible to affirm that the samples are homogeneous concerning the PSD and the variable that determines greater differences between samples is $\mathrm{D}_{50}$. For the chemical characterization, TOC is the variable that presents a more significant variation concerning HM; that is, the higher concentrations of TOC, the lower HM concentrations. In previous results [12], an MCA analysis was carried out to find the relationships between the physical, chemical, and hydrological characteristics of the sediments showing that the higher $\mathrm{Pb}$ and $\mathrm{Cu}$ concentrations are associated to fine particles $(\leq 75 \mu \mathrm{m})$. These results agree with the results obtained by [34]. Also, at higher rainfall intensity, thinner sediments are transported by the runoff; likewise, for more days in dry weather, higher HM concentrations and lower TOC were found. These results also agree with those obtained by [35], [36].

Figure 7. PCA
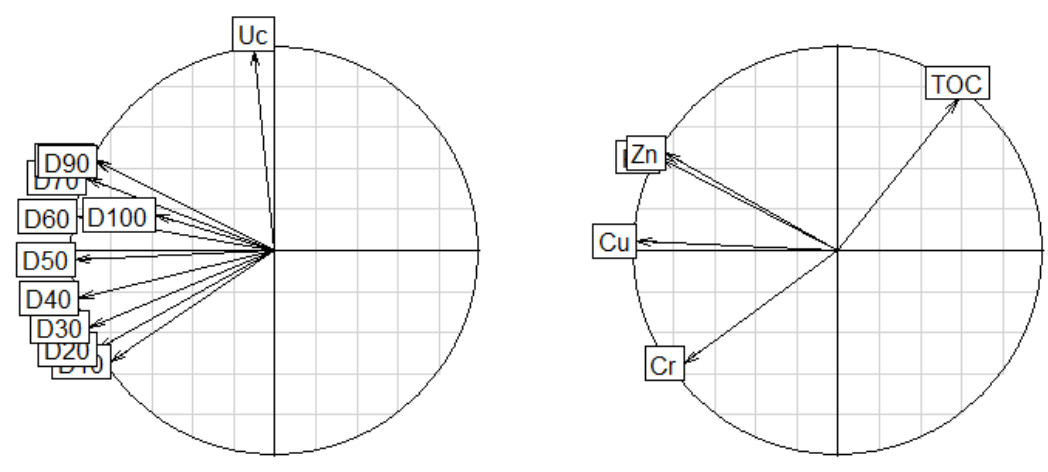

Source: Own source.

Four hydrological scenarios were proposed based on the results obtained to determine, if possible, better sediment quality conditions. The $1^{\text {st }}$ takes the high values of Htot and Iprom, showing a decrease of $5 \%$ in HM concentrations. The $2^{\text {nd }}$ takes the high values of Tlluvia and lower values of Tseco, obtaining a decrease of $25 \%$ for $\mathrm{Cu}, \mathrm{Cr}$, and $\mathrm{Pb}$ and $5 \%$ for $\mathrm{Zn}$ concentrations; additionally, TOC is present and increases in $15 \%$. The $3^{\text {rd }}$ takes the 
high values for Ipromneta, showing an increase of $10 \%$ for HM concentrations and a decrease of $5 \%$ for TOC concentrations. The $4^{\text {th }}$ takes the average values of Imax, obtaining a decrease of $15 \%$ for HM concentrations and an increase of $5 \%$ for TOC concentrations. These scenarios do not show significant differences compared to the previously established uses possibly due to $\mathrm{Pb}$ and $\mathrm{Zn}$ concentrations present in the sediments, which exceed the established limits for agricultural use, and also because the high TOC values restrict its use in construction.

\section{Conclusions}

According to the Colombian legislation, the sediments collected from the CWST sand traps are considered suitable to be used in activities such as the remediation and revegetation of soils that are not for agricultural use. However, it is necessary to consider that the receiving soil has lower or worse characteristics than the sediments. Likewise, according to the high TOC concentrations obtained, the use should be limited as a filling material for concrete structures and culverts in the core or foundation area. Finally, it is not possible to use the sampled sediments in activities related to agriculture because of the high levels of HM obtained.

In order to establish better sediment management options, it is necessary to analyze the sediments of different wetlands or rainwater structures taking into account the anthropogenic aspects of the study areas and the costs involved in these analyses. For this reason, these results can be used as a first approximation to sediment reuse.

From the analysis of the results of the physical and chemical characteristics of the sediments, the latter are the most influential in the possible use of sediments as a productive material, due to the high concentrations of $\mathrm{Pb}$ and $\mathrm{Zn}$. These concentrations come mostly from the wear of the vehicle tires, the brakes, and the oils and lubricants that are used in the automotive industry [37].

The relationship between the hydrology and the physical characteristics of the sediments showed that the higher rainfall intensity, and the higher number of days in dry weather, the higher HM concentrations, contrary to what happens with TOC concentrations, which tend

to decrease. These last results open the possibility of proposing sediment management systems based on the hydrological behavior in the study area. This implies lower costs associated with the management of sediments and more timely response times. Further studies will deepen these relationships to estimate critical characteristics of the sediments that provide elements for making decisions regarding their use without the need for systematic or frequent sediment characterizations. 


\section{References}

[1] SedNet, L. Palumbo, and G. Bortone, Sediment and Dredged Material Treatment. Amsterdam: Elsevier Science, 2007.

[2] Y. X. Chen, G. W. Zhu, G. M. Tian, G. D. Zhou, Y. M. Luo, and S. C. Wu, "Phytotoxicity of dredged sediment from urban canal as land application," Environ. Pollut., vol. 117, no. 2, pp. 233241, Apr. 2002. Available: https://doi.org/10.1016/S0269-7491(01)00270-6

[3] Y.-C. Jang, P. Jain, T. Tolaymat, B. Dubey, S. Singh, and T. Townsend, "Characterization of roadway stormwater system residuals for reuse and disposal options," Sci. Total Environ., vol. 408, no. 8, pp. 1878-1887, Mar. 2010. Available: https://doi.org/10.1016/j.scitotenv.2010.01.036

[4] K. Walter, G. Gunkel, and N. Gamboa, "An assessment of sediment reuse for sediment management of Gallito Ciego Reservoir, Peru,” Lakes Reserv. Sci. Policy Manag. Sustain. Use, vol. 17, no. 4, pp. 301-314, 2012. Available: https://doi.org/10.1111//re.12008

[5] A. Akcil, C. Erust, S. Ozdemiroglu, V. Fonti, and F. Beolchini, "A review of approaches and techniques used in aquatic contaminated sediments: metal removal and stabilization by chemical and biotechnological processes," J. Clean. Prod., vol. 86, no. Supplement C, pp. 24-36, Jan. 2015. Available: http://dx.doi.org/10.1016/j.jclepro.2014.08.009

[6] R. Ashley, J.-L. Bertrand-Krajewski, T. Hvitved-Jacobsen, and M. Verbanck, "4.1 Solids control at sources and at inputs to sewerage systems," in Solids in Sewers. London: IWA Publishing, 2004, pp. 210-251. Available: https://doi.org/10.2166/9781780402727

[7] Y.-L. Cheng, H.-M. Wee, P.-S. Chen, Y.-Y. Kuo, and G.-J. Chen, "Innovative reservoir sediments reuse and design for sustainability of the hydroelectric power plants," Renew. Sustain. Energy Rev., vol. 36, pp. 212-219, Aug. 2014. Available: https://ideas.repec.org/a/eee/rensus/v36y2014icp212219.html

[8] L. Wang, J. S. H. Kwok, D. C. W. Tsang, and C.-S. Poon, "Mixture design and treatment methods for recycling contaminated sediment," J. Hazard. Mater., vol. 283, no. Supplement C, pp. 623-632, Feb. 2015. Available: https://doi.org/10.1016/j.jhazmat.2014.09.056

[9] R. Fonseca, F. Barriga, and W. S. Fyfe, "Reversing desertification by using dam reservoir sediments as agriculture soils," Episodes, vol. 21, pp. 218-224, 1998.

[10] J. Vaze and F. H. S. Chiew, "Nutrient loads associated with different sediment sizes in urban stormwater and surface pollutants," J. Environ. Eng., vol. 130, no. 4, pp. 391-396, Apr. 2004. Available: https://doi.org/10.1061/(ASCE)0733-9372(2004)130:4(391)

[11] F. J. Charters, T. A. Cochrane, and A. D. O'Sullivan, "Particle size distribution variance in untreated urban runoff and its implication on treatment selection," Water Res., vol. 85, no. Supplement C, pp. 337-345, Nov. 2015. Available: https://pubmed.ncbi.nlm.nih.gov/26343992/

[12] M. A. Pimiento, D. S. Rivera, J. A. Lara-Borrero, and A. Torres, "Relación entre las características hidrológicas, físicas y químicas de sedimentos presentes en escorrentía de aguas lluvias," Ing. Compet., vol. 20, no. 2, pp. 27-36, 2018. Available: https://doi.org/10.25100/iyc.v20i2.5846

[13] K. M. Camponelli, S. M. Lev, J. W. Snodgrass, E. R. Landa, and R. E. Casey, "Chemical fractionation of $\mathrm{Cu}$ and $\mathrm{Zn}$ in stormwater, roadway dust and stormwater pond sediments," Environ. Pollut., vol. 158, no. 6, pp. 2143-2149, Jun. 2010. Available: https://doi.org/10.1016/j.envpol.2010.02.024

[14] C. J. Cedeño Ochoa, "Metales en agua por Plasma Acoplado por Inducción $(\mathrm{Cd}, \mathrm{Cr}, \mathrm{Cu}, \mathrm{Ni}, \mathrm{Pb}$, Zn)," Ideam, Subdirección de Hidrología-Grupo Laboratorio de Calidad Ambiental, Oct. 30, 2006. Available:

http://www.ideam.gov.co/documents/14691/38155/Metales+en+agua+por+Plasma+Acoplado+por+I nducci\%C3\%B3n..pdf/d4946215-8e8f-4262-bab2-b236139cfcc8 
[15] Canadian Council of Monisters of the Environment, Canadian Sediment Quality Guidelines for the Protection of Aquatic Life, 2001. https://www.elaw.org/system/files/sediment_summary_table.pdf

[16] Wisconsin Dept. of Natural REsources, Consensus-Based Sediment Quality Guidelines Recommendations for Use \& Application, 2003. Available: https://dnr.wi.gov/files/PDF/pubs/rr/RR088.pdf

[17] Ministerie van Volkshuisvesting, "Dutch Target and Intervention Values," Feb. 04, 2000. https://www.esdat.net/environmental\%20standards/dutch/annexs_i2000dutch\%20environmental\%20 standards.pdf

[18] Norwegian Environment Agency, Risk assessment of contaminated sediments, vol. M-1132, 2018. https://www.miljodirektoratet.no/globalassets/publikasjoner/m1132/m1132.pdf

[19] Australian and New Zealand Environment and Conservation Council, Australian and New Zealand Guidelines for Fresh and Marine Water Quality. ANZECC, 2000. https://www.waterquality.gov.au/sites/default/files/documents/anzecc-armcanz-2000-guidelinesvol1.pdf

[20] Ove Arup \& Partners Hong Kong Ltd., "EIA Report," 2009. https://www.epd.gov.hk/eia/register/english/permit/vep2822008/documents/emar200909/pdf/emar20 0909.pdf

[21] Ministerio de Vivienda, Ciudad y Territorio, Reglamento Técnico del Sector de Agua Potable y Saneamiento Básico-RAS: Título F Sistemas de Aseo Urbano. Bogotá: Ministerio de Vivienda, $\begin{array}{llll}\text { Ciudad } & \text { y } & \text { Territorio, } & \text { Available: }\end{array}$ http://www.minvivienda.gov.co/Documents/ViceministerioAgua/TITULO\%20F.pdf

[22] R. Canet, C. Chaves, F. Pomares, and R. Albiach, "Agricultural use of sediments from the Albufera Lake (eastern Spain)," Agric. Ecosyst. Environ., vol. 95, no. 1, pp. 29-36, Apr. 2003. Available: https://doi.org/10.1016/S0167-8809(02)00171-8

[23] S. Galarza-Molina, A. Torres, J. Lara-Borrero, S. Méndez-Fajardo, L. Solarte, and L. González, "Towards a constructed wetland/reservoir-tank system for rainwater harvesting in an experimental catchment in Colombia," Ing. Univ., 2015. Available: https://doi.org/10.11144/Javeriana.iyu192.tcws

[24] E. Juárez Badillo and A. Rico Rodríguez, Mecánica de suelos. México: Limusa 2012.

[25] United States Environmental Protection Agency, SW-846 Test Method 3051A: Microwave Assisted Acid Digestion of Sediments, Sludges, Soils, and Oils, 2016. Available: https://www.epa.gov/hwsw846/sw-846-test-method-3051a-microwave-assisted-acid-digestion-sediments-sludges-soils-andoils

[26] Environment Protection Authority Tasmania, Tasmanian Biosolids Reuse Guidelines. 1999.

[27] Danish Environmental Protection Agency, "Soil", in Environmental Factors and Health, 2001. Available: $\quad$ https://www2.mst.dk/udgiv/publications/2001/87-7944-5195/html/helepubl_eng.htm\#6\%20Soil

[28] M. B. Pescod and N. Rome, Food and Agriculture Organization of the United. Rome: FAO, 1992.

[29] United States Environmental Protection Agency, Biosolids Technology Fact Sheet Land Application of Biosolids. Washington, D. C.: EPA, Sept. 2000. Available: https://www3.epa.gov/npdes/pubs/land_application.pdf

[30] H. Snyman and J. Herselman, "Selection of management options," in Guidelines for the Utilisation and Disposal of Wastewater Sludge, 2nd ed., vol. 1. Republic of South Africa, 2006, 1-76.

[31] Laboratorio Nacional de Materiales y Modelos Estructurales, Manual centroamericano de especificaciones para la construcción de carreteras y puentes regionales. Costa Rica: Lanamme, Mar. 2001.

[32] Instituto Nacional de Vías, "Artículo 610-13, Rellenos para estructuras," 2012. Available: http://gerconcesion.co/invias2013/610\%20RELLENOS\%20PARA\%20ESTRUCTURAS.pdf 
[33] A. Pérez, J. Cárdenas, C. A. Peña-Guzmán, and A. Torres, "Sediments settled in stormwater sewer systems: assessment of possible uses through quality analysis," presented at NOVATECH 2016, Lyon, Francia, 2016.

[34] C. Gunawardana, P. Egodawatta, and A. Goonetilleke, "Role of particle size and composition in metal adsorption by solids deposited on urban road surfaces," Environ. Pollut., vol. 184, pp. 44-53, Jan. 2014. https://doi.org/10.1016/j.envpol.2013.08.010

[35] M. del P. R. Barreiro, R. D. P. Castañeda, and C. A. Zafra Mejía, "Evaluación temporal de la concentración de metales pesados asociada con el sedimento vial: Fontibón-Barrios Unidos (Bogotá D. C., Colombia)," Ing. Univ. Eng. Dev., vol. 19, no. 2, pp. 69-87, Jul. 2015. https://doi.org/10.11144/Javeriana.iyu19-2.etcm

[36] R. J. Winston and W. F. Hunt, "Characterizing runoff from roads: Particle size distributions, nutrients, and gross solids," J. Environ. Eng., vol. 143, no. 1, pp. 1-12, Jan. 2017. https://doi.org/10.1061/(ASCE)EE.1943-7870.0001148

[37] J. M. Trujillo-González, "Evaluación de tres zonas de la ciudad de Villavicencio a partir de las concentraciones de metales pesados presentes en el polvo vial," M. S. thesis, Fac. Cienc. Nat. Ing., Univ. Jorge Tadeo Lozano, Bogotá, Colombia, 2014. Available: https://expeditiorepositorio.utadeo.edu.co/bitstream/handle/20.500.12010/1762/T056.pdf?sequence= 1\&isAllowed=y 